\title{
Niels W. Gade og Carl Nielsen i et nyt og bredere perspektiv
}

afprofessor, dr.phil. Finn Egeland Hansen

På det internationale Carl Nielsen Symposium "Carl Nielsen. Inheritance and Legacy" på Det Kongelige Bibliotek i november 2011 holdt forfatteren nedenstäende indlag, der her bringes i dansk oversattelse som optakt til Niels W. Gade-jubilaet i 2017. Indlagget er en proveballon, der forhåbentlig vil skabe oget interesse for at betragte to af de storste danske komponister $i$ et nyt og bredere perspektiv end det snevert nationale, som hidtil har domineret forskningen. Forfatteren er professor emeritus i musikvidenskab ved Danmarks Larerhøjskole og Aalborg Universitet og hovedredaktor af den internationale, praktisk-videnskabelige udgave af Niels W. Gade Works / Werke, hvoraf der indtil 2016 er udkommet 21 bind, ${ }^{1}$ og som Det Kongelige Biblioteks Center for Musikudgivelse bidrager til. I 2006 udgav Det Kongelige Bibliotek endvidere et af hans musikteoretiske hovedverker, Layers of Musical Meaning. ${ }^{2}$

Artiklen henviser til citater fra en rakke indspilninger. Disse citater kan findes samlet pa: $<$ www.kb.dk/da/nb/publikationer/magasin/egeland > (eller benyt QR-koderne).

$\mathrm{D}$ enne artikel foregiver ikke at være en videnskabeligt dokumenteret og gennemarbejdet studie, men snarere en præsentation af forskellige observationer gjort over en årrække vedrørende musikalske strømninger i det 19. og 20. århundrede. Det er mit håb, at disse observationer på et tidspunkt i fremtiden vil kunne underbygges og sluttelig føje detailler af en vis betydning til vores forståelse af musikken i perioden 1850 til 1950.

Strømninger i det 19. århundredes musik De fleste musikhistoriebøger - i hvert fald dem, jeg kender til - præsenterer på den ene eller den anden måde, i nogle tilfælde eksplicit, i de fleste mere indirekte, en tredeling af de vigtigste musikalske strømninger i det 19. århundrede.

Den første er en romantisk strømning, som udviser en naturlig udvikling og udbygning af den klassiske æras musi- kalske udtryksmidler. Denne strømning udfolder sig i det væsentlige inden for den klassiske musiks veletablerede genrer såsom symfoni, sonate, koncert og en vifte af kammermusikalske genrer, blandt hvilke strygekvartetten indtager en privilegeret stilling.

De fremmeste eksponenter for denne strømning - som ofte kaldes klassiskromantisk - er Felix Mendelssohn Bartholdy, Robert Schumann og Johannes Brahms, og blandt komponisterne hen imod slutningen af århundredet nævnes Anton Bruckner ofte.

Den anden er den såkaldt nytyske retning, hvis karakteristika kan sammenfattes som forsøg på at tilskrive eller tillægge musikalske værker ekstramusikalsk mening, det være sig af konkret art som i egentlig programmusik eller mere eller mindre vage stemninger eller følelser. Med Berlioz som tidlig bebuder var de førende komponister inden for denne 


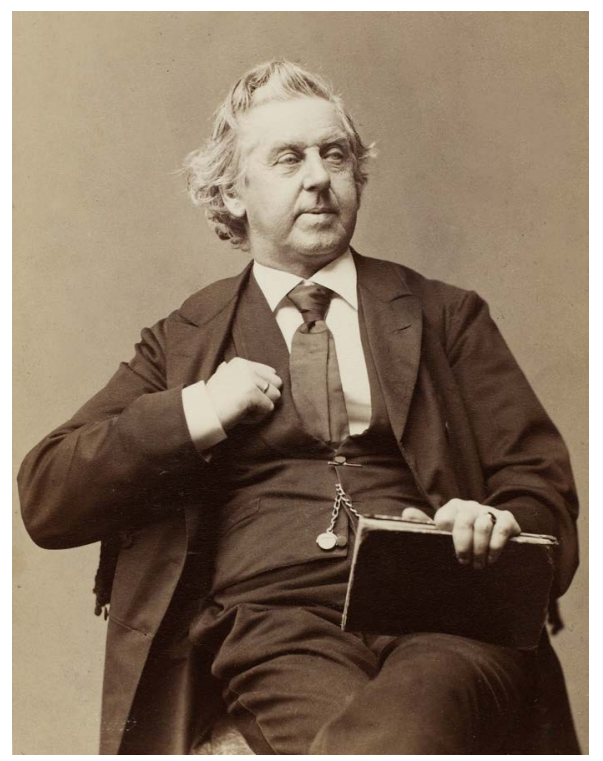

Niels W. Gade (1817-1890)

retning Richard Wagner og Franz Liszt med Richard Strauss som en efternøler af formidabel dimension.

Den tredie retning er en nationalromantisk strømning, karakteristisk ved, at musikken indeholder elementer udtrukket af lokal folkemusik - instrumental eller vokal. Alle hjørner af Europa, det tidligere Tjekkoslovakiet, Polen, Ungarn, Rusland, de nordiske lande og Storbritannien ikke at forglemme, bidrager til denne hovedstrømning med fremragende komponister.

Det siger sig selv, at hver af disse tre hovedstrømninger undergår sin egen specifikke stiludvikling i løbet af århundredet; men også, at disse i en vis udstrækning blander sig med hinanden og udviser visse fællestræk, herunder en tendens til stedse mere kompleks harmonik, anvendelse af stadigt større orkestre med tredobbelt træblæserbe- sætning, store slagtøjsgrupper, en eller flere harper, kor og vokalsolister. Alt dette kombineret med en tendens til, at værkerne bliver længere og længere. Kort sagt: Det sene 1800-tals værker lider i stigende grad af en form for musikalsk gigantisme eller ligefrem gigantitis (hvis dette ord ellers fandtes).

Min hovedpointe er nu, at man bør føje en fjerde strømning til de tre ovenfor omtalte, nemlig en strømning, som i sin afvisning af den musikalske gigantisme, stræber mod større enkelhed og mådehold både med hensyn til de ydre instrumentale og vokale ressourcer og de indre stilistiske træk. Følgelig vil værker, der udspringer af disse bestræbelser kunne udvise et antal klassicistiske træk, en art retroklassicisme, som meget let kan forveksles med stagnation eller ligefrem reaktion. Men denne retroklassicisme skal snarere anskues som budbringer for det 20 . århundredes neoklassicisme.

\section{Niels W. Gades stiludvikling}

Da Niels W. Gade kickstartede sin kompositoriske karriere i 1841 med Ossianouverturen, var hans udgangspunkt ideen om en national-romantisk udtryksform baseret på en melodisk idiomatik hentet fra den danske folkevisemelodik. Og for den omgivende verden, dvs. Gades publikum, den danske presse og dens anmeldere og senere danske musikforskere, var dette den sande Gade.

Da Gade i 1843 drog til Leipzig for at fremme sin karriere, kom han under stærk indflydelse fra Mendelssohn og Schumann og de klassisk-romantiske ideer. $\mathrm{Og}$ groft sagt vekslede Gades musikalske stil - i det mindste for en periode - mellem det national-romantiske og det klassisk- 
romantiske. To meget populære og næsten samtidige værker, Elverskud, skabt i perioden 1851-54, og Frühlingsphantasie fra 1852 illustrerer på eksemplarisk vis disse to musikalske udtryksformer, og hvorledes Gade var i stand til helt gnidningsløst at skifte mellem dem.

Men Gades publikum var ikke fordomsfri over for de forskellige udtrykslag i hans musik. I Musikkens historie $i$ Danmark skriver Nils Schiørring: "I løbet af 1850 'erne vandt han sin dominerende position i dansk musikliv i kraft af, hvad han havde skabt, i kraft af den nimbus, der stod om ham fra årene i Leipzig, og på dansk grund lyste en glorie over næsten alt, hvad han foretog sig. Forsøgte han sig en sjælden gang ad nye baner, fik han at høre, at han var på vildspor. Man ville have ham, som man kendte ham, og det affandt han sig med." ${ }^{3}$

Lad os lytte til et kort brudstykke fra et af Gades national-romantiske værker, åbningen af Ossianouverturen. Her møder vi mange karakteristiske træk i hans national-romantiske stil:

1) Et harmonisk sprog, i hvilket flere detailler afviger fra skarpskåret kadenceharmonik.

2) En melodik inspireret af danske folkevisemelodier. Hovedtemaets lighed med melodien til balladen om Ramund nævnes ofte i denne sammenhæng.

3) En instrumentation (eller sound), som signalerer mystik, skygge og mørke, flettet sammen med lyden fra harpe som associerer til barden, der akkompagnerer sig selv på dette instrument.

\section{$\therefore$ \\ Eksempel}

1

Og nu begyndelsen af 1 . sats fra Frühlingsphantasie, et såkaldt koncertstykke for fire vokalsolister og orkester med dets mere gennemsigtige instrumentation, tematiske struktur og skarpskårne kadenceharmonik. Det instrumentale forspil er udformet som ekspositionsdelen af en sonatesats med et hovedtema i g-mol spillet tre gange (i klaver, klarinet og fuldt orkester) samt et sidetema i den kontrasterende toneart B-dur:
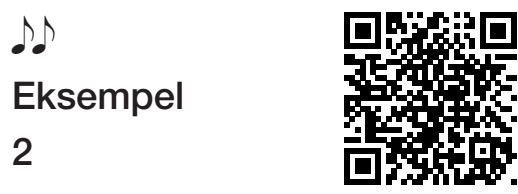

Hvis vi nu retter blikket mod den nytyske retning og Niels W. Gade, er det ikke vanskeligt at overbevise sig om, at dette ikke var noget, den danske komponist viede megen opmærksomhed. Det eneste værk, som nærmer sig Wagner i stil og udtryk er Baldurs Drøm fra 1858. Men den recitativiske melodik, som Gade dyrker i dette værk, passede ikke det københavnske publikum - og Gade vendte aldrig tilbage til den.

Efter 1860 må Gades primære udtryksmåde siges at være den klassisk-romantiske. Men det synspunkt, at hans musik ikke udviklede sig nævneværdigt, er fordomsfuldt. Lyt til disse to korte eksempler fra finalen af 7. symfoni og 3. sats af 8. symfoni. 

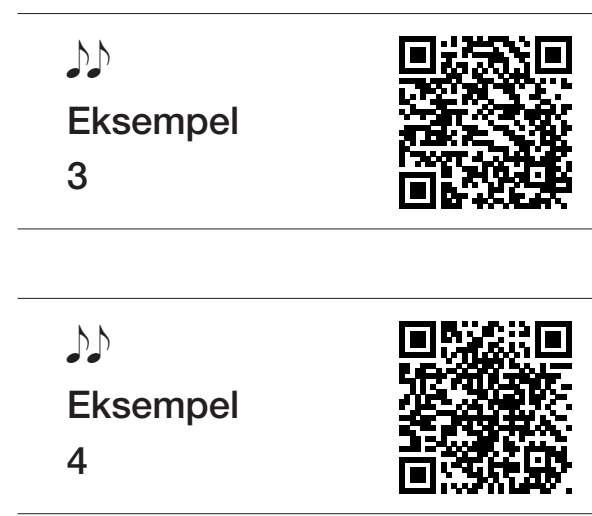

Passager, som så overbevisende integrerer instrumentation og intensitet i de musikalske ideer, finder man ikke i de tidligere værker.

Der er mere sandhed i den påstand, at han i sin lejlighedsvise tilbagevenden til en folkemusikinspireret udtryksform ikke udviste noget nyt og revolutionerende. Det skal dog bemærkes, at hans op. 62, Folkedanse i nordisk karakter for violin og klaver, bygger på instrumentale snarere end vokale idiomer.

Men så tidligt som i 1850'erne viser der sig værker med en klassisk klarhed som overgår det typisk klassisk-romantiske værk. Det første af disse værker er den 4. symfoni, som skulle blive et af hans mest populære værker og tilmed en af de hyppigst opførte europæiske symfonier overhovedet $\mathrm{i}$ anden halvdel af det 19. århundrede.

Hvis dette værk havde været et enkeltstående eksempel, kunne man have betragtet det som den enlige svale, der som bekendt ikke gør nogen sommer.

Men 4. symfoni var ikke et isoleret og enkeltstående eksempel. I et ikke ubetydeligt antal værker dukker denne ekstraordinære klassiske klarhed op igen og igen: F.eks. i klavertrioen op. 43, kantaten Zion op. 49, de to sæt novelletter for strygere op. 53 og op. 58, den 3. violinsonate op. 59 og strygekvartetten op. 63.

Om op. 63 har en af mine københavnske kolleger udtalt, at han fandt D-durkvartetten et fremragende værk, blot var dets kompositionstidspunkt helt forkert. Jeg er imidlertid overbevist om, at den musikalske stil i disse værker er resultatet af grundige overvejelser fra Gades side - og ikke blot resultatet af tilfældige udsving i en stagnerende klassisk-romantisk stil.

Hertil kommer, at vi også støder på sådanne manifestationer af ekstraordinær klassisk klarhed i andre europæiske lande, og efter min opfattelse repræsenterer de en begyndende reaktion mod den tiltagende gigantisme i europæisk musik.

Lad os høre begyndelsen af Gades Novelletter op. 58 for strygeorkester og umiddelbart derefter begyndelsen af den næsten samtidige Serenade for strygeorkester af Anton Dvořák.
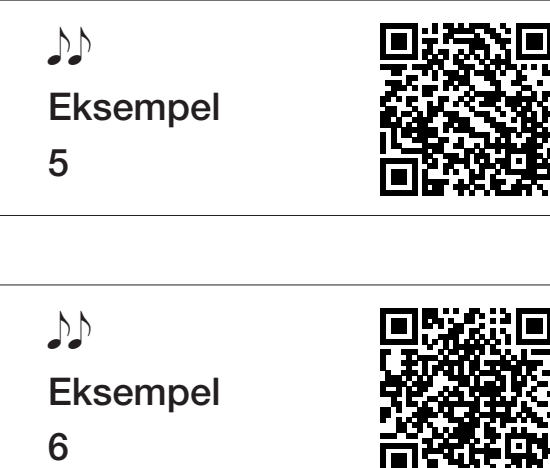

Sådanne retroklassicistiske værker findes hos mange europæiske komponister, og det er måske ikke en tilfældighed, at det er hos en franskmand, denne tendens er tydeligst, nemlig hos Charles Gounod, hvis 
livsløb var stort set sammenfaldende med Gades. Hans to symfonier fra 1850 'erne og Petite symphonie for dobbelt blæserkvintet fra 1885 ligger helt på linie med andre retroklassicistiske værker.

Den retroklassicistiske udtryksform kan siges at nå sin kulmination i Prokofievs Klassiske symfoni fra 1916-17, som - på samme tid - almindeligvis betragtes som startskuddet til den neo-klassicistiske strømning i det 20. århundrede.

\section{Musikalske strømninger i det}

\section{0. århundredes første halvdel}

Vi vender nu blikket mod det 20. århundrede, som udviser en langt mere kompleks struktur af musikalske strømninger end det 19. århundrede. To strømninger er imidlertid forholdsvis lette at identificere, nemlig:

1) Den neoklassicistiske strømning og

2) Den folkloristiske strømning

Den folkloristiske strømning er en fortsættelse af den national-romantiske strømning i det 19. århundrede, men med et langt bredere spektrum af måder, hvorpå de folkemusikalske elementer kan inddrages. Sammenlign f.eks. brugen af folkemusikalsk materiale i Bela Bartóks strygekvartetter med den måde, det gøres på af 1800-tallets komponister.

Vort hovedfokus her er den neoklassicistiske strømning, som kan defineres ved dens reaktion mod det sene 1800 -tals gigantisme. Den omfatter en meget bred vifte af komponister med Igor Stravinsky, Paul Hindemith og den franske gruppe Les Six som tæller Francis Poulenc, Arthur Honneger, Darius Milhaud, Germaine Taillifere, Georges Auric og Louis Durey som de mest fremtrædende.
Jean Cocteau var vigtig i forbindelse med Les Six. I hans skriverier forlanger han, at 'silkebørsten skal erstattes af øsen,' en henvisning til dagligdags håndværk, som franskmændene fandt skulle være en central del af deres kunst. Carl Nielsen kommer tæt på dette synspunkt. I et brev fra 1904 til sin kone skriver han: "Lad os huske at Kunst er som alt andet: en jevn menneskelig Ting og slet ikke noget for sig. Vort Arbejde er aldeles ikke mere værd eller har en højere Rang end den beskedne Haandværkers eller Forretningsmands. Du regner ikke Mennesker som ikke kan tale fint om Kunst og Videnskab. Jeg vilde hellere være en sund, stærk Bondekarl med frodige Sanser og appetitlig Livslyst end jeg vilde være Ove Jørgensen som jeg holder meget af." ${ }^{\prime \prime}$ Ove Jørgensen var klassisk filolog og en nær ven af Nielsen-familien.

På det internt musikalske plan er neoklassicismen - blandt andet - karakteristisk ved at bekende sig til tonalitet, omend i en meget fri fortolkning af fænomenet, omfattende Stravinskys antitonalitet, Milhauds polytonalitet og i visse tilfælde tonalitet på grænsen til atonalitet.

\section{Carl Nielsen}

Med hensyn til Carl Nielsen har danske musikforskere været utilbøjelige til at karakterisere Nielsen og hans værk som neoklassicistisk - selv om han passer perfekt ind i det generelle billede af denne strømning. Jeg husker en episode fra mine år ved Aarhus Universitet. Jeg nævnte for en af mine kolleger muligheden af at betragte Nielsen som neoklassicist. Svaret var: "Nuvel, det er da et synspunkt" akkompagneret af en afvisende gestus, som mere end antydede, at jeg havde overskredet grænsen til kulturelt forræderi. 
I Gads Musikleksikon (fra 2003) skriver Bo Foltmann modigt: "I de senere værker udviklede han derimod en mere kammermusikalsk stil, påvirket af tidens neoklassicistiske bevægelse. Dette kommer blandt andet til udtryk i den 6. symfoni (192425) samt i fløjte- og klarinetkoncerten, der adskiller sig fra de tidligere orkesterværker gennem en mindre besætning og mere transparent tekstur. Neoklassicistiske træk er også fremtrædende i blæserkvintetten (1922), mens orgelværket Commotio tager udgangspunkt i barokkens formsprog."

Nielsens bleserkvintet er et fint eksempel på et værk i neoklassicistisk stil - både med hensyn til form, melodi og harmoni. Den rytmiske stil udviser derimod ikke den brug af hyppigt skiftende taktarter, som var så typisk for Stravinsky og Hindemith, i mindre grad for de franske neoklassicister.

Blæserkvintetten er komponeret $\mathrm{i}$ 1922, hvilket er bemærkelsesværdigt tidligt, eftersom de velkendte kammermusikværker for sammenlignelige besætninger af Poulenc, Milhaud, Jean Françaix, Jacques Ibert, Eugène Bozza og mange andre er blevet til mindst ti år senere.

Lad os høre et kort stykke i typisk Nielsen-stil mht. tekstur, melodidannelse og duften af kirketonalitet. Hvorfor dette værk ikke har fundet vej til den samlede Nielsen-udgave er ikke godt at vide, men her er det:

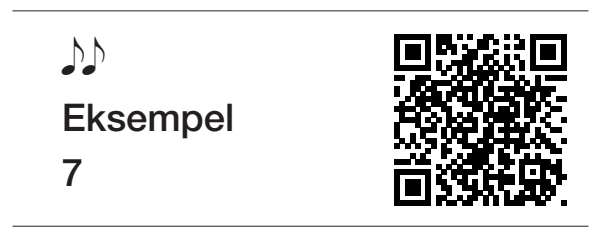

En mulig forklaring på dets udelukkelse fra Nielsen-udgaven er, at det ikke er kom-

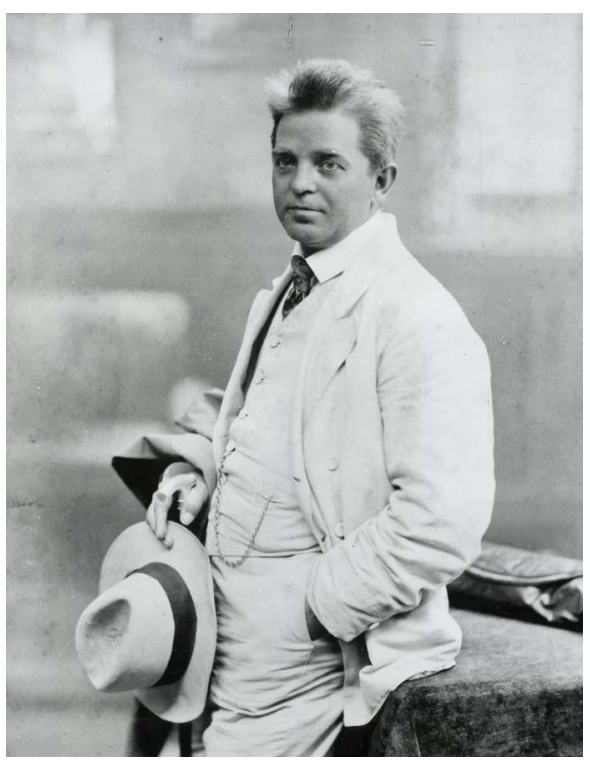

Carl Nielsen (1865-1931)

poneret af Nielsen, men af Eugène Bozza ca. 20 år efter Nielsens død.

\section{Afslutning}

Det er mit håb, at denne korte præsentation har godtgjort eksistensen af en samtidig reaktion mod den musikalske gigantisme i anden halvdel af det 19. århundrede. Vi får se, hvorvidt det er muligt at underbygge denne reaktion som en selvstændig strømning eller skole, eller blot som et antal indbyrdes uafhængige frembringelser af forskellige komponister. I det 20. århundrede opnåede den neoklassicistiske strømning tydeligvis mere styrke, men ikke nødvendigvis mere ensartethed. Hvad fremtidige studier end måtte nå frem til i så henseende, føler jeg mig overbevist om, at Gade og Nielsen begge har deltaget aktivt i reaktionen mod den oppustede musikalske stil i det sene 1800-tal. 


\section{Musikeksempler på <www.kb.dk/da/nb/publikationer/magasin/egeland>}

Eksempel 1: Niels W. Gade: Ossian-ouverturen, Op. 1

DR SymfoniOrkestret / Christopher Hogwood

Chandos Chan 9795

Eksempel 2: Niels W. Gade: Frühlings-Phantasie, Op. 23, 1. sats

Copenhagen Phil / Michael Schønwandt

Da Capo, Marco Polo, 8.224051

Eksempel 3: Niels W. Gade: Symfoni nr. 7, Op. 45, Finale

DR SymfoniOrkestret / Christopher Hogwood

Chandos Chan 9957

Eksempel 4: Niels W. Gade: Symfoni nr. 8, Op. 47, Andante

DR SymfoniOrkestret / Christopher Hogwood

Chandos Chan 9862

Eksempel 5: Niels W. Gade: Novelletter for strygeorkester, Op. 58, 1. sats

Aarhus Kammerorkester / Ove Vedsten Larsen

Paula PACD 12

Eksempel 6: Antonín Dvořák: Serenade for strygere, Op. 22, 1. sats

Camerata Bern / Thomas Furi

Novalis 150 011-2

Eksempel 7: Eugène Bozza: Trois pièces pour une musique de nuit, 1. sats

Selandia Ensemble

Kontrapunkt 32032

\section{Noter}

1 Niels W. Gade Works / Werke. Published by the Foundation for the Publication of the Works of Niels W. Gade / Herausgegeben von der Stiftung zur Herausgabe der Werke Niels W. Gades. Series I: Orchestral Works; Series II: Chamber Music; Series III: Works for Keyboard Instruments; Series IV: Choral Works; Series V: Solo Songs; Series VI: Music for the Stage: Series VII: Arrangements and Supplements. Distribution: Engstrøm \&
Sødring og Bärenreiter Verlag: København \& Kassel, 1995ff., [Foreløbig:] 21 bind, flere under udgivelse $2016 \mathrm{ff}$.

2 Finn Egeland Hansen: Layers of Musical Meaning. The Royal Library: Museum Tusculanum Press, 2006, xii, 336 pp. Ill. (Danish Humanist Texts \& Studies vol. 33).

3 Musikkens historie i Danmark. Bind 1-3. København, 1977-78. Citat bind 2, s. 301.

4 John Fellow (udg.): Carl Nielsen Brevudgaven, bind 2, 2006, brev nr. 393, s. 417f. 